\title{
Soil conditions under a Fagus sylvatica CONECOFOR stand in Central Italy: an integrated assessment through combined solid phase and solution studies
}

\author{
Soil Science Department, University of Florence, Piazzale Cascine 15, 50144 Florence, Italy \\ ${ }^{1)}$ Istituto Sperimentale per lo Studio e la Difesa del Suolo, Firenze, Italy \\ ${ }^{2}$ U.O. Tutela Risorse Idriche, ARPAT, Dipartimento Provinciale di Firenze, Italy \\ *e-mail corresponding author: cecchini@iges.fi.cnr.it
}

Guia CECCHINI*, Stefano CARNICELLI, Aldo MIRABELLA ${ }^{1)}$, Francesco MANTELLII $^{2)}$ and Guido SANESI

\begin{abstract}
As soil solution represents the major phase of soil chemical reactions, its study is a powerful tool for ecological investigations. Soil solution chemical composition gives a realistic idea about the soil chemical components immediately available in the environment, mainly in relation to the soil ecosystem reaction to the disturbance due to acidifying loads. Within the CONECOFOR Program, the monitoring of forest soil conditions was performed in a level II plot (ABR I), under a Fagus sylvatica (European beech) stand, through the study of throughfall and soil solutions collected from depths ranging between the base of the litter layers and $90 \mathrm{~cm} . T 0$ be able to investigate solution contents of nutrients, acidifying agents and DOC throughout the profile, both zero tension and tension lysimeters were used. The first ones were inserted below the organic horizons, while tension lysimeters were placed within the mineral horizons at 15, 25, 55 and $90 \mathrm{~cm}$ depth. Sampled solutions were analyzed for $\mathrm{Na}, \mathrm{K}, \mathrm{Ca}, \mathrm{Mg}, \mathrm{NH}_{4}, \mathrm{Cl}, \mathrm{F}, \mathrm{NO}_{3}, \mathrm{SO}_{4}$, and $\mathrm{DOC}$. The results evidence a clear seasonal pattern, mainly for macronutrients and inorganic $N$ components. Acidic pulses were mostly evident below the organic horizons, in relation to strong nitric $N$ releases from litter; these last were not always immediately neutralized by basic cations. Acid solutions leaving the organic horizons were invariably neutralized in the surface mineral horizons, within $15 \mathrm{~cm}$ depth. Temporal patterns of sulphate retention and release suggest that the soil has low retention capability for this anion. Such behaviour can be explained by the composition of the solid phase, where potential anion adsorbants appear strongly linked with organic matter in long residence time complexes. Sulphate and nitrate loading of this soil appear, anyway, to be mostly non-anthropogenic, but rather linked to natural mineralization pulses and, for sulphate, to aeolian solid transport from the south.
\end{abstract}

Key words: lisimetry, assessment, acidification, beech, soil solution

\section{INTRODUCTION}

Soil solution is the medium of soil chemical reactions (Adams 1974). If the study of the soil solid phase gives good information about the factors and processes that influenced and influence soil genesis, solution chemistry is a powerful tool in understanding active pedogenic processes. For environmental research, soil solution composition provides information on the distribution of nutrients inside the profile (Litaor 1988), allows the detection of potential hazards for the soil-environment equilibrium, such as acidification due to anthropogenic pollution, and provides crucial information concerning acid neutralizing capacity (ANC) of a soil system (David \& Driscoll 1984).

In the last decades, the study of soil solution has been extensively used in several monitoring programs in north-west Europe, to assess the status of forest soils subjected to long-term acid loading. Such inputs caused soil and surface water acidification, and $\mathrm{SO}_{4}$ accumulation in the soil (Bredemeier 1987; Meesenburg et al. 1995; Ulrich et al. 1980). Subsequently, as air pollution legislation was introduced to reduce acidifying inputs into the atmosphere, processes in the soil compartment reversed, and release of previously stored polluting loads was observed. The study of soil solutions was therefore used in experiments to predict the reversibility of soil acidification, both in natural systems and under experimentally reduced acid inputs (Alewell et al. 1997; Marschner et al. 1998).

In Italy, monitoring of forest soils is performed within the national CONECOFOR Program, developed in the framework of UN/ECE and EU activities. Soil investigations in the 26 established level II sites (Allavena et al. 1999) outlined the existence of soils susceptible to acidification risks. Within this program, soil solution monitoring started in 1999 in two level II sites, ABR1 and LAZ1.

This paper presents soil solution data gathered in 1999 together with data from previous research in site ABR1, with the aim of ascertaining the current soil status, checking the influence of possible acidifying inputs on pedogenetic processes, and evaluating the environmental implications for the forest condition.

\section{METHODS}

\subsection{Study Area}

Site ABR1 is located on a $5-10^{\circ}$ south facing slope, in a hanging valley in the upper slopes of the calcareous Serra Lunga ridge, in the Abruzzo Apennines. The val-

Paper prepared within the CONECOFOR programme, by the contract with the Ministry for Agriculture and Forestry Policy - National Forest Service, Italy. CONECOFOR is part of the Pan-European Level II Intensive Monitoring of Forest Ecosystem and is co-sponsored by the European Commission. 
ley may have originated as a karst closed depression, subsequently opened up by erosion but preserving a gently sloping floor. Bedrock is a hard, stratified, Cretaceous-age limestone. As is usual with this kind of bedrock, uncertainty about actual soil parent material stems from the basic observation that the non-calcareous fraction of the rock is much too small to account for the volumes of non-calcareous soil observed. The term "Terra Rossa" is used to refer to such fine material, of uncertain origin and probably made up of a mixture of limestone residue, aeolian depositions and other material. In this area, a relevant contribution from air-fall volcanic ashes is known (Ferrari \& Malesani 1973)

The site is at an altitude of $1600 \mathrm{~m}$ a.s.1.; yearly average temperature is $10{ }^{\circ} \mathrm{C}$, with marked seasonal excursions. Yearly equivalent rainfall is around $1300 \mathrm{~mm}$ (Allavena et al. 1999). Precipitation is mostly concentrated in the fall-spring period, when a large portion falls as snow. Snow cover usually lasts for 4 to 5 months.

The site is within a European beech (Fagus sylvatica L.) highstand, about 100 years old. The forest appears to have been long managed as a highstand (Matteucci 1998). Until about 1960, however, it was subjected to rather intense cutting, including fuelwood harvesting, with peaks coinciding with both the second World War and the reclamation of the nearby Fucino basin. The area was, and formally still is, subject to wood and litter harvesting rights vested in the local population; there has however been a marked decline in such practices in the last decades, and litter has not been harvested for at least 30 years.

Vegetation studies (Matteucci et al. 1997) revealed that $80 \%$ of beech roots are concentrated in the upper 50 $\mathrm{cm}$ of soil; leaf cover begins to appear in the first half of May and the vegetative season lasts until mid-October.

\subsection{Soil and soil solution analyses}

Two soil profiles were described, according to USDA-SSDS (1993), within the ABR1 site, after a series of auger checks for soil spatial variability. Profiles were sampled on a horizon basis, and analyzed for $\mathrm{pH}$ (in $\mathrm{H}_{2} \mathrm{O}, \mathrm{KCl}$ and $\mathrm{NaF}$ ), organic $\mathrm{C}$, exchangeable bases, exchangeable Al, particle size distribution, DCB, Acid $\mathrm{NH}_{4}$-oxalate and Na-phyrophosphate extractable Fe, Al, $\mathrm{Si}$ and C, according to van Reeuwijk (1992). Clay mineralogy was studied as described in Carnicelli et al. (1997).

Soil solution sampling was performed according to Regulation 1390/97 (EU), Submanual on Soil Solution Collection and Analysis (Annex III-4 and 5, and Annex 1-1). Within the plot, the following samplers were set up: zero-tension lysimeters, inserted under the organic horizons in four replicates along a trench; tension lysimeters (P 80, Staatliche Porzellan-Manufaktur, Berlin, Germany), inserted at 15, 25 and $55 \mathrm{~cm}$ depth, and tension lysimeters (PTFE, Prenart), at $90 \mathrm{~cm}$ depth in two replicates. Tension lysimeters were inserted as threeunit clusters at the same depth, clusters at different depths being separated to avoid mutual interference; clusters were spaced over an area checked as homogeneous to profile 1 by auger holes. The lysimeters, inserted a few years ago, appeared to be well equilibrated and to meet the requirements of the Regulation.

Stainless-steel zero-tension lysimeters were inserted, at a shallow slope, to avoid waterlogging in the sampler. All lysimeters were pre-treated with $0.1 \mathrm{M} \mathrm{HCl}$, and rinsed with distilled water until the $\mathrm{AgNO}_{3}$ test gave a negative result.

Samplers were normally inspected every second week; however, no sampling was possible during the period of thick snow cover, while in the summer months soil water was often held at a higher tension than could be extracted by the lysimeters. Samples from existing throughfall funnels, not normalized to volume, were also analyzed, in order to get information about chemical inputs at the soil surface. Following every collection, vacuum was applied individually to each suction cup, adjusted to about $-500 \mathrm{hPa}$. Solution samples were analyzed, on reaching the laboratory, for $\mathrm{pH}$ (potentiometry, Titroprocessor 670, Metrohm) and electrical conductivity (EC) (Micro CM 2201, Crison). The remaining solution, filtered $(45 \mu \mathrm{m}$ membrane filters cellulose acetate, MFS) and stored in the dark at $4{ }^{\circ} \mathrm{C}$, was analyzed for the following parameters: $\mathrm{Cl}, \mathrm{NO}_{3}, \mathrm{SO}_{4}$, $\mathrm{NH}_{4}$ (ion chromatography, Dionex DX 120), Na, K, Ca, $\mathrm{Mg}$, (AAS, Perkin Elmer 372), DOC (TOC analyser Astro 2001 T2).

\section{RESULTS}

\subsection{Main soil properties}

The soil in site ABR1, as described in table 1, is rather complex in its field appearance. The stack of dark, organic-rich, A and AB horizons is fairly thick, suggesting accumulation of deposited materials. Depositions relate both to local geomorphic processes, as the site is liable to accumulation of soil sediments from upper slopes, and to known events of volcanic ash fall (Malesani \& Ferrari 1973).

Augering revealed some soil spatial variability, mostly in the depth of solum and individual horizons; the two profiles represent typical cases of maximum (profile 1) and minimum (profile 2) depth. In profile 1, horizon sequence is interrupted by a pocket, representing a filled erosion channel. As seen in table 2, soil material in this pocket differs significantly from the main horizons only as regards its content of organic matter. Relevant considerations on soil genesis and soil acidification relations apply to all observed materials, including the profile described in the original level II survey of the site (Alianiello et al. 2001).

The main soil characteristics in relation to forest soil acidification risks are acidity and base status. Most horizons (Tab. 2) are quite acid, with water $\mathrm{pH}<5$, excep- 
Tab. 1. Field description of soil profile 1 .

\begin{tabular}{|c|c|c|}
\hline Depth & Hour. & \\
\hline $2-1$ & Oil & Undecomposed beech leaves \\
\hline $1-0$ & $\mathrm{Oe}$ & Partially decomposed beech leaves \\
\hline $0-4 / 6$ & A1 & $\begin{array}{l}\text { Dark brown, } 7.5 \text { YR } 3 / 2 \text {, moist; silty loam; medium to fine, strong, crumb structure; very } \\
\text { friable, plastic, slightly sticky; abundant, very fine to medium, roots; abrupt wavy boundary } \\
\text { to: }\end{array}$ \\
\hline $4 / 6-30$ & $\mathrm{~A} 2$ & $\begin{array}{l}\text { Dark brown, } 7.5 \text { YR } 3 / 2 \text {, moist; silty loam; coarse and medium, strong, subangular blocky } \\
\text { structure, dividing in medium crumb; friable, plastic, slightly sticky; abundant, very fine to } \\
\text { medium, roots; abrupt smooth boundary to: }\end{array}$ \\
\hline $30-55 / 57$ & $\mathrm{AB}$ & $\begin{array}{l}\text { Very dark brown, } 7.5 \text { YR } 2.5 / 2 \text {, moist; loam to silty loam; coarse and medium, strong, } \\
\text { subangular blocky structure, dividing in medium crumb; friable, plastic, slightly sticky; } \\
\text { common, very fine to medium, roots; abrupt wavy boundary to: }\end{array}$ \\
\hline $55 / 57-85$ & $2 \mathrm{BAb}$ & $\begin{array}{l}\text { Brown, } 7.5 \text { YR } 4 / 4 \text {, moist; silty clay; coarse, moderate, subangular blocky structure, dividing } \\
\text { into fine blocky subangular; firm, very plastic, very sticky; few roots; abrupt smooth } \\
\text { boundary to: }\end{array}$ \\
\hline $85-115+$ & $3 \mathrm{Btb}$ & $\begin{array}{l}\text { Brown, 7.5YR } 4 / 4 \text { moist; clay; fine and medium, moderate, angular blocky structure, } \\
\text { gathering into weak coarse angular blocky; discontinuous clay coatings on ped faces; very } \\
\text { firm, very plastic, very sticky; very few roots. }\end{array}$ \\
\hline
\end{tabular}

Tab. 2. Basic physical and chemical properties of the soil solid phase.

\begin{tabular}{|c|c|c|c|c|c|c|c|c|c|c|c|c|c|c|c|}
\hline \multirow{3}{*}{$\begin{array}{l}\text { Soil profile } \\
\text { and horizon }\end{array}$} & & & & \multirow{3}{*}{ Sand } & \multirow{3}{*}{$\begin{array}{l}\text { Clay } \\
(\%)\end{array}$} & \multirow{3}{*}{ Silt } & \multirow{3}{*}{$\begin{array}{l}\text { Org. C } \\
\left(\mathrm{g} \mathrm{kg}^{-1}\right)\end{array}$} & \multicolumn{5}{|c|}{ Ex bases } & \multirow{3}{*}{ Ex. Al } & \multirow{3}{*}{$\begin{array}{r}\text { ECEC } \\
(\%)\end{array}$} & \multirow{3}{*}{ Base sat } \\
\hline & \multicolumn{3}{|c|}{$\mathrm{pH}$} & & & & & $\mathrm{Na}$ & $\mathrm{K}$ & $\mathrm{Ca}$ & $\mathrm{Mg}$ & Sum & & & \\
\hline & $\mathrm{H}_{2} \mathrm{O}$ & $\mathrm{KCl}$ & $\mathrm{NaF}$ & & & & & & & 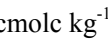 & & & & & \\
\hline \multicolumn{16}{|l|}{ Profile 1} \\
\hline $\mathrm{A} 1$ & 5.54 & 4.98 & 7.9 & & & & 142.5 & 0.22 & 1.66 & 26.20 & 3.62 & 31.70 & 0.00 & 31.7 & 100 \\
\hline $\mathrm{A} 2$ & 4.68 & 4.07 & 9.5 & 6.1 & 44.1 & 49.7 & 77.7 & 0.22 & 0.54 & 6.99 & 0.86 & 8.61 & 3.67 & 12.3 & 70 \\
\hline $\mathrm{AB}$ & 4.78 & 4.13 & 10.3 & 5.5 & 51.1 & 43.4 & 58.6 & 0.22 & 0.38 & 4.99 & 0.51 & 6.11 & 3.89 & 10.0 & 61 \\
\hline $2 \mathrm{BAb}$ & 4.97 & 3.99 & 9 & 9.0 & 44.9 & 46.1 & 8.1 & 0.38 & 0.58 & 9.23 & 1.28 & 11.46 & 3.89 & 15.4 & 75 \\
\hline $3 \mathrm{Btb}$ & 5.34 & 3.97 & 8.8 & 15.3 & 43.5 & 41.2 & 7.2 & 0.22 & 0.51 & 12.72 & 1.36 & 14.81 & 2.89 & 17.7 & 84 \\
\hline $\mathrm{AB}$ (pocket) & 4.68 & 4.03 & 9.2 & 6.1 & 48.5 & 45.4 & 19.7 & 0.33 & 0.58 & 6.24 & 1.19 & 8.33 & 5.22 & 13.6 & 61 \\
\hline \multicolumn{16}{|l|}{ Profile 2} \\
\hline $\mathrm{A} 1$ & 5.11 & 4.65 & 8.4 & 4.3 & 55.3 & 40.5 & 140.0 & 0.33 & 1.34 & 23.70 & 2.26 & 27.63 & 0.11 & 27.7 & 100 \\
\hline $\mathrm{A} 2$ & 4.65 & 4.02 & 9 & 4.9 & 48.8 & 46.3 & 64.1 & 0.33 & 0.45 & 8.23 & 1.40 & 10.41 & 4.00 & 14.4 & 72 \\
\hline BA & 4.93 & 3.96 & 9.2 & 10.7 & 44.9 & 44.4 & 11.5 & 0.43 & 0.70 & 9.73 & 1.56 & 12.43 & 4.33 & 16.8 & 74 \\
\hline
\end{tabular}

tions being the $\mathrm{A} 1$ and $3 \mathrm{Btb}$ horizons. The $\mathrm{pH}$ decrease in $\mathrm{KCl}$ is more marked in the $2 \mathrm{BAb}$ and $3 \mathrm{Btb}$ horizons, where it is $\geq 1$ point, as against $\approx 0.5$ in the overlying horizons; this difference is related to different compositions of the exchange complex, which are discussed below. Base status is correlated to $\mathrm{pH}$ in water; in this case, the A1 horizons stand out more sharply, due to their high exchangeable $\mathrm{Ca}$ and the absence of exchangeable Al. This differentiation is related to the high turnover of base cations, typical of deciduous species. Calcium and other basic cations are constantly resupplied at the soil surface by the rapidly decomposing litter, and also penetrate to some extent below the surface, as indicated by the somewhat better base status of A2 than AB. In any case, as the A1 horizons are fairly thin, the soil has to be considered definitely acid.

A second major issue concerns the pools of "active" metal forms, i.e. metals included in non-silicate minerals, poorly-ordered minerals, or organo-metallic complexes. These solid phases are important as a potential source of toxic Al (Robarge \& Johnson 1992). On the other hand, especially at low soil $\mathrm{pH}$, they develop anion adsorption properties, fostering soil interactions with anthropogenic acidifying anions, such as sulfate (Johnson et al. 1986). Results of the selective dissolution of "active" Fe, Al and Si forms are presented in table 3. The most evident result is the high content of Fe and $\mathrm{Al}$, extractable both in Na-pyrophosphate (Fep, Alp) and in acid $\mathrm{NH}_{4}$-oxalate (Feo, Alo). These fractions are intended to represent, respectively, organically-bound metals and the sum of organically-bound and poorly-ordered mineral forms. For Al, the Alp value, higher than that of Alo, is an index of inadequate selectivity of this dissolution method (Kaiser \& Zech 1996), especially in view of the clay mineralogy of the soil (vide infra). Nevertheless, the pool of "active" Al and $\mathrm{Fe}$ forms in this soil must be regarded as large. The nature of these forms can be better understood if we compare the different results, keeping in mind the contribution of volcanic ash to the parent material. The low or very low Sio values, with respect to Alo, indicate that very little Alo comes from poorly-ordered aluminosilicates. The high Alp values, notwithstanding the problems with the method, rather suggest a major contribu- 
Tab. 3. Results of selective dissolution analyses for extractable forms of Al, Fe and Si. DCB: extractable in Dithionite-citrate-bicarbonate Ox: extractable in acid $\mathrm{NH}_{4}$-oxalate P: extractable in Na-pyrophosphate * Imogolite-type minerals, as estimated from $\mathrm{Si}$ Ox content.

\begin{tabular}{|c|c|c|c|c|c|c|c|c|c|c|}
\hline \multirow{2}{*}{$\begin{array}{l}\text { Soil profile } \\
\text { and horizon }\end{array}$} & \multirow[t]{2}{*}{ Fed } & \multirow[t]{2}{*}{ Ald } & Feo & Alo & Sio & ITM* & \multirow[t]{2}{*}{ Fep } & \multirow[t]{2}{*}{ Alp } & \multirow[t]{2}{*}{$\mathrm{Cp}$} & \multirow[t]{2}{*}{$(\mathrm{Fep}+\mathrm{Alp}) / \mathrm{Cp}$} \\
\hline & & & \multicolumn{4}{|c|}{$\left(\mathrm{g} \mathrm{kg}^{-1}\right)$} & & & & \\
\hline \multicolumn{11}{|l|}{ Profile 1} \\
\hline A1 & 20.69 & 9.74 & 10.22 & 11.68 & 1.17 & 8.31 & 7.3 & 11.68 & 39.07 & 0.49 \\
\hline $\mathrm{A} 2$ & 24.1 & 13.23 & 11.34 & 13.71 & 1.32 & 9.37 & 8.98 & 14.18 & 32.65 & 0.71 \\
\hline $\mathrm{AB}$ & 25.76 & 18.18 & 11.36 & 17.68 & 2.02 & 14.34 & 8.59 & 20.2 & 33.33 & 0.86 \\
\hline $2 \mathrm{BAb}$ & 23.16 & 9.45 & 9.45 & 13.23 & 1.51 & 10.72 & 3.78 & 9.45 & 9.12 & 1.45 \\
\hline $3 \mathrm{Btb}$ & 25.77 & 6.09 & 7.5 & 9.37 & 0.94 & 6.67 & 1.17 & 4.22 & 11.42 & 0.47 \\
\hline
\end{tabular}

tion from the organically-bound fraction (Al-humus complexes). This hypothesis is also supported by the high values of Na-pyrophosphate extractable Fe and, especially, organic carbon (Cp). Such a distribution of extractable metal forms is characteristic of a specific type of soil deriving from volcanic ash, defined by the terms "nonallophanic Andosol" (Shoji et al. 1993), and "Alu-andic horizon" (ISSS-ISRIC-FAO 1998). Another typical characteristic of this soil type is the (Fep + $\mathrm{Alp}) / \mathrm{Cp}$ ratio, which estimates the degree of metal loading of the complexing organic acids (Shoji et al. 1993). In the soil studied, this ratio is extremely high; metalhumus complexes with this degree of metal loading are to be considered immobile, as confirmed by the absence of any depth accumulation trend for active metal forms.

Low pedogenetical homogeneity is indicated by marked differences in many parameters between the upper (A1 to $\mathrm{AB}$ ) and lower (2BAb and $3 \mathrm{Btb}$ ) horizons. In the latter, the properties and processes discussed up to now emerge to a lesser extent. On the other hand, clay translocation is evident from field morphology, but not confirmed by particle size analysis. We interpret this discrepancy as the result of soil genesis from a layered parent material; we also identified two lithological discontinuities, marked by the letters 2 and 3 used for the lower horizons' designations. Only the upper lithological discontinuity, however, appears to correspond to a boundary between different soil types, formed under different conditions. We believe that the lower horizons result from a single pedogenesis, the soil thus formed being later buried by a different parent material, over which a new soil has developed; the suffix b (buried), used for the lower horizons, derives from this interpretation.

The pedological discontinuity is also revealed by some very basic data. For the upper horizons there are clear discrepancies between field texture estimation and analytical particle size determination, while there is good agreement for the lower ones. The discrepancy is due to the presence, in the upper horizons, of a larger amount of organo-metallic complexes and poorly-ordered $\mathrm{Fe} / \mathrm{Al}$ oxides. These phases are clay-sized, and are accounted as such in the laboratory analysis; their physical behavior, however, is quite different from that of silicate clay, and these materials do not feel like clay in the field. Further evidence is provided by the different behavior of $\mathrm{pH}$ in water and $\mathrm{KCl}$ in the two horizon groups. The $\mathrm{pH}$ decrease in $\mathrm{KCl}$ is due to the exchange between $\mathrm{K}$ and adsorbed $\mathrm{Al}$; this last then gives acid hydrolysis in solution. Within similar materials, the decrease is closely, and inversely, related to absolute $\mathrm{pH}$ values. In this soil, however, very acid horizons, such as A2, show a small decrease, while a much less acid horizon like $3 \mathrm{Btb}$ shows a marked decrease. The components of the exchange complex are clearly not the same; in the upper horizons, organic and oxide adsorbants exchange Al less readily than the dominant silicate clays of the lower horizons.

The complex genesis of this soil means that, with an appropriately flexible interpretation of the WRB system (ISSS-ISRIC-FAO 1998), it can be classified as Aluandic Umbrisol over Dystric Luvisol.

\subsection{Clay mineralogy}

A further soil solid phase influencing soil reactions in acidification processes is made up of clay minerals. $\mathrm{X}$-ray diffraction traces of four representative horizons are shown in figure 1. It must be stressed that this analysis is directed only at silicate clay minerals, and does not refer to other clay-sized solid phases, such as the organo-metallic complexes and poorly ordered oxides of the upper horizons.

Three main groups of minerals are readily evident: Kaolinite, identified by the peak at $0.72 \mathrm{~nm}$, which disappears after heating at $550{ }^{\circ} \mathrm{C}$; micaceous minerals, identified by the peak at $1.0 \mathrm{~nm} ; 2: 1$ expandable minerals are identified by the peak at $1.4 \mathrm{~nm}$, which strongly decreases after heating at $335^{\circ} \mathrm{C}$. On further heating, at $550{ }^{\circ} \mathrm{C}$, this last peak is reduced to a very low intensity, showing that there is only a small contribution from the 2:1:1 Chlorite family. Micaceous minerals are inherited from the soil parent material, specifically from its nonvolcanic component. Their relative abundance, as inferred from peak areas, decreases regularly towards the surface, due to progressive weathering. Kaolinite is ubiquitous in well-developed soils in central Italy; it partly derives from aeolian additions and partly from feldspar weathering in acid soils. 2:1 expandable minerals de- 

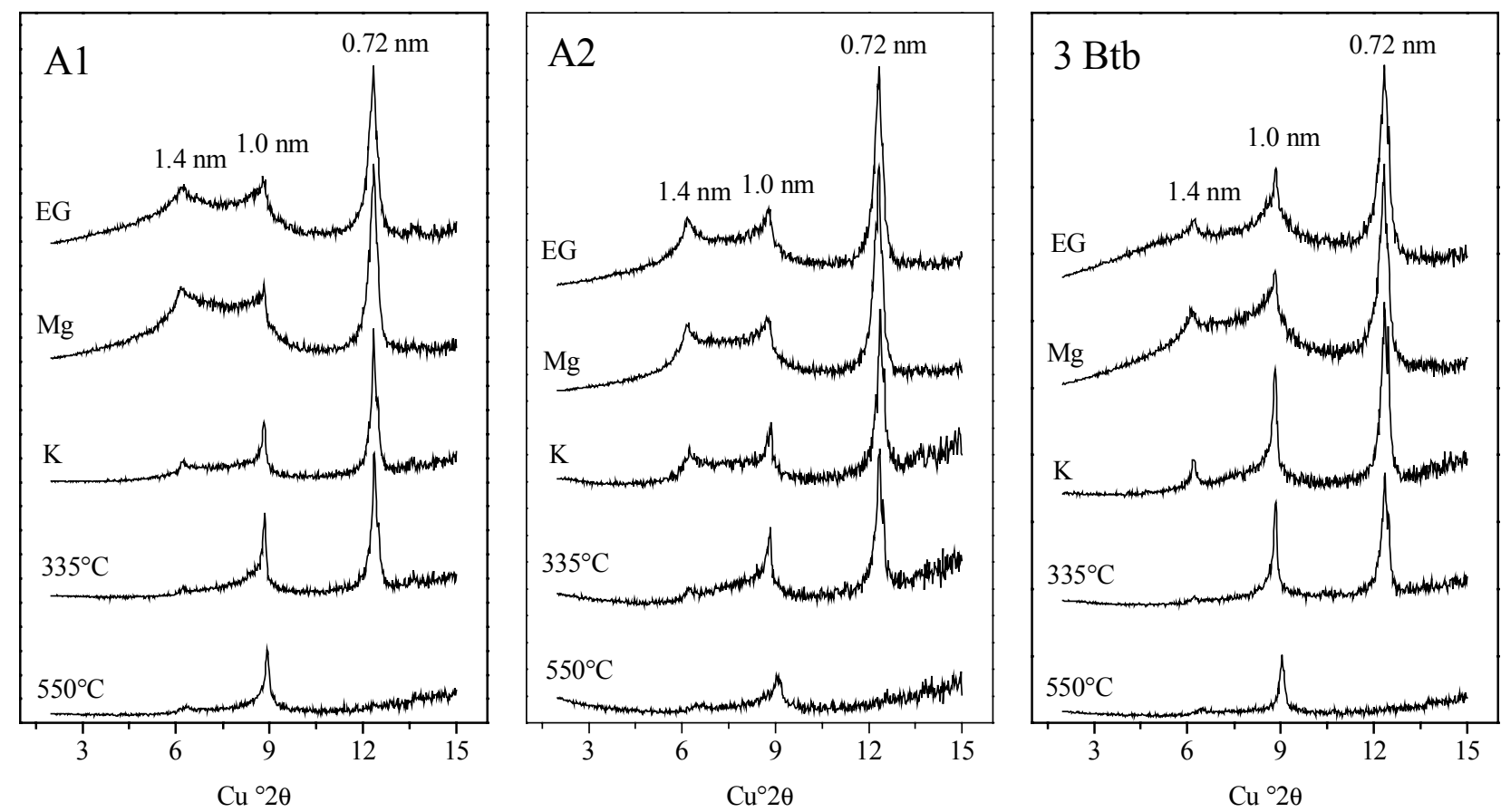

Fig. 1. Clay fraction X-ray diffraction patterns of selected horizons of profile 1. Diagnostic treatments are indicated besides the traces, as follows: EG: Ethylen-glycol solvated; Mg: Mg-saturated; K: K-saturated; $335{ }^{\circ} \mathrm{C}$ : K-saturated and heated at $335{ }^{\circ} \mathrm{C}$ for 2 hours; $550{ }^{\circ} \mathrm{C}$ : same at $550^{\circ} \mathrm{C}$.

serve a more comprehensive analysis. Absence of reaction to the EG treatment excludes the presence of Smectite minerals; the minerals present appear to belong to the Vermiculite family. Their relative abundance increases towards the surface, and they appear to form mostly from solid-state weathering of micaceous minerals. Most X-ray traces show a wide, noise-like but intense diffraction in the region between 1.0 and $1.4 \mathrm{~nm}$, attributable to randomly interstratified mica-vermiculite minerals, i.e. to ensembles of micaceous layers at various stages of transformation into vermiculite ones. The minerals present are not, however, or not completely, simple vermiculites. Reaction to $\mathrm{K}$ saturation and heating shows that the interlayer region of such minerals is not freely accessible to cations, but, to different extents, occupied by assemblages of Al-hydroxy polymers. Such assemblages form from the progressive polymerisation of exchangeable $\mathrm{Al}$, which is thus blocked and made non-exchangeable. This process is general in acid soils containing 2:1 clay minerals (Barnhisel \& Bertsch 1989, Carnicelli et al. 1997). The minerals thus formed are generally referred to as HIM (hydroxy-interlayered minerals) or HIV (hydroxy-interlayered vermiculites). HIV are much more stable than Vermiculite in acid soils, possibly indefinitely stable, except in the presence of highly active organic complexing agents (Carnicelli et al. 1997). In nonallophanic Andosols, HIM are the typical dominant 2:1 clay minerals, as the complexing agents are rapidly saturated by the large amounts of metals released by ash weathering (Shoji et al. 1993). Interlayer Al is partly dissolved by $\mathrm{Na}$-pyrophosphate extraction (Kaiser \& Zech 1996), thus creating anomalies in the results obtained by this method. The Al-sink actions of HIM and organic complexing agents act synergically, inhibiting the formation of the minerals typical of allophanic Andosols, such as Imogolite, Allophane and Halloysite. Vermiculite and HIV form a continuous, the degree of hydroxy interlayering being estimated by the reactions of the $1.4 \mathrm{~nm}$ and $1.0 \mathrm{~nm}$ peaks to $\mathrm{K}$ saturation and heating. 2:1 layers react to these treatments by contracting from 1.4 to $1.0 \mathrm{~nm}$, but at different steps. While Al-free layers contract with $\mathrm{K}$ saturation, Al-occupied layers contract on heating, due to dehydroxylation of the Al polymers. Resistance to dehydroxylation is a rough function of the amount of such polymers.

The X-ray traces in figure 1 show that the degree of Al occupancy is not homogeneous. A1 horizons show very low occupancy, while in A2 the situation is reversed. Intermediate occupancy is visible in the lower horizons. Such irregularities are partly due to the chemical environment of the horizon, which shows clear relations with $\mathrm{pH}$ in water, but are also a reflection of the lithological and pedological discontinuities present in this soil.

\subsection{Throughfall and soil solutions}

The main parameters of sampled soil solutions for the year 1999 are summarized in table 4. 
Tab. 4. Selected chemical parameters of soil solutions collected in 1999 at site ABR1; *: sum of Ca, $\mathrm{Mg}, \mathrm{Na}$ and $\mathrm{K} ;{ }^{* *}$ difference between total amount of cations and total amount of anions

\begin{tabular}{|c|c|c|c|c|c|c|c|c|c|c|c|}
\hline \multirow[t]{2}{*}{ depth } & \multirow[t]{2}{*}{ date } & \multirow[t]{2}{*}{$\mathrm{pH}$} & $\mathrm{Na}$ & $\mathrm{K}$ & $\mathrm{Ca}$ & $\mathrm{Mg}$ & $\Sigma$ Bases* & $\mathrm{NO}_{3}$ & $\mathrm{SO}_{4}$ & Deficit** & \multirow{2}{*}{$\begin{array}{l}\text { DOC } \\
\mathrm{mg} \mathrm{l}^{-1}\end{array}$} \\
\hline & & & \multicolumn{8}{|c|}{$\mu \operatorname{mol}(\mathrm{c}) 1^{-1}$} & \\
\hline TF & $16 / 5 / 99$ & 6.2 & 29.0 & 15.1 & 31.5 & 15.2 & 90.8 & 0 & 18.0 & 53.5 & 6.2 \\
\hline-15 & & 6.3 & 67.7 & 7.6 & 131.6 & 34.8 & 241.7 & 5.6 & 37.2 & 147.2 & 4.4 \\
\hline-25 & & 6.3 & 65.9 & 9.7 & 187.4 & 32.5 & 295.4 & 3.9 & 40.9 & 186.1 & 6.2 \\
\hline-55 & & 6.8 & 59.6 & 5.9 & 572.4 & 38.7 & 676.5 & 0.0 & 53.2 & 558.4 & 2.6 \\
\hline-90 & & 6.8 & 77.6 & 22.4 & 500.2 & 47.4 & 647.7 & 0.0 & 57.2 & 504.2 & 3.1 \\
\hline $\mathrm{TF}$ & $11 / 6 / 99$ & 6.6 & 26.1 & 163.8 & 137.6 & 63.8 & 391.3 & 0 & 41.1 & 429.5 & 14.9 \\
\hline litter & & 6.2 & 83.6 & 89.0 & 254.5 & 78.9 & 505.9 & 59.4 & 51.6 & 291.9 & 16.1 \\
\hline-15 & & 6.4 & 58.7 & 4.2 & 98.6 & 26.1 & 187.6 & 6.8 & 39.1 & 83.0 & 5.7 \\
\hline-25 & & 6.3 & 63.2 & 4.9 & 150.9 & 25.2 & 244.3 & 10.6 & 39.0 & 143.1 & 7.2 \\
\hline-55 & & 6.8 & 63.4 & 5.9 & 609.3 & 32.1 & 710.7 & 0.0 & 48.3 & 617.4 & 2.8 \\
\hline-90 & & 6.9 & 57.9 & 15.7 & 659.2 & 28.4 & 761.3 & 0.0 & 53.1 & 662.1 & 2.7 \\
\hline $\mathrm{TF}$ & $8 / 7 / 99$ & 6.7 & 44.6 & 132.6 & 239.0 & 59.5 & 475.7 & 37.4 & 55.8 & 454.8 & 19.7 \\
\hline litter & & 6.4 & 37.0 & 171.7 & 250.5 & 87.8 & 547.0 & 238.3 & 45.7 & 237.6 & 24.8 \\
\hline-15 & & 6.8 & 92.2 & 19.0 & 215.9 & 65.3 & 392.4 & 7.9 & 44.3 & 266.6 & 6.6 \\
\hline-25 & & 6.8 & 53.4 & 11.9 & 143.2 & 26.5 & 235.0 & 2.4 & 44.9 & 140.5 & 7.1 \\
\hline-55 & & 7 & 60.3 & 4.6 & 576.8 & 28.9 & 670.7 & 0.0 & 43.2 & 569.9 & 4.3 \\
\hline-90 & & 6.9 & 52.9 & 17.6 & 194.1 & 27.5 & 292.1 & 0.0 & 60.8 & 179.1 & 3.4 \\
\hline $\mathrm{TF}$ & 27/7/99 & 6.6 & 63.5 & 83.1 & 226.5 & 51.8 & 424.9 & 60.0 & 58.3 & 255.7 & 13.5 \\
\hline litter & & 6.6 & 68.3 & 298.7 & 1343.8 & 310.1 & 2020.9 & 1317.5 & 144.1 & 589.8 & 35.8 \\
\hline-15 & & 5.8 & 101.1 & 39.6 & 201.1 & 42.8 & 384.5 & 32.2 & 67.4 & 177.6 & 10.8 \\
\hline-25 & & 6.3 & 77.9 & 25.4 & 158.7 & 29.5 & 291.5 & 28.3 & 57.2 & 128.2 & 8.8 \\
\hline-55 & & 6.7 & 69.6 & 6.1 & 322.5 & 26.9 & 425.1 & 0.0 & 40.3 & 308.3 & 4.3 \\
\hline $\mathrm{TF}$ & 4/9/99 & 6.7 & 20.0 & 35.4 & 157.9 & 30.9 & 244.2 & 10.1 & 42.3 & 175.1 & 6.3 \\
\hline litter & & 5.0 & 27.8 & 176.4 & 615.6 & 162.5 & 982.4 & 636.0 & 62.2 & 266.2 & 21.1 \\
\hline-15 & & 7.4 & 99.2 & 24.0 & 669.2 & 162.7 & 955.0 & 31.4 & 83.7 & 772.3 & 7.5 \\
\hline-25 & & 6.6 & 104.0 & 21.4 & 92.7 & 31.7 & 249.8 & 7.1 & 66.4 & 89.4 & 13.3 \\
\hline TF & $5 / 10 / 99$ & 5.9 & 40.9 & 98.3 & 83.5 & 15.8 & 238.5 & 5.0 & 26.1 & 151.7 & 6.4 \\
\hline litter & & 5.1 & 43.9 & 266.4 & 1096.8 & 280.4 & 1687.5 & 1357.0 & 64.5 & 330.1 & 40.7 \\
\hline-15 & & 6.1 & 60.9 & 0.4 & 132.3 & 27.4 & 221.0 & 46.0 & 51.1 & 77.5 & 8.7 \\
\hline-25 & & 6.3 & 70.1 & 13.3 & 217.4 & 29.8 & 330.5 & 0.0 & 65.8 & 195.8 & 21.2 \\
\hline TF & 27/10/99 & 6.4 & 30.0 & 79.4 & 68.3 & 12.5 & 190.2 & 3.4 & 43.0 & 112.5 & 4.8 \\
\hline litter & & 5.9 & 31.3 & 168.1 & 441.2 & 98.3 & 738.9 & 343.2 & 33.8 & 346.1 & 27.2 \\
\hline-15 & & 6.4 & 62.8 & 9.9 & 558.5 & 66.0 & 697.3 & 13.2 & 46.2 & 568.4 & 5.4 \\
\hline-25 & & 6.5 & 61.1 & 10.8 & 176.6 & 26.0 & 274.4 & 0.0 & 48.3 & 159.8 & 9.1 \\
\hline-55 & & 6.8 & 67.8 & 4.0 & 1104.8 & 15.0 & 1191.6 & 0.0 & 65.3 & 1051.9 & 4.4 \\
\hline $\mathrm{TF}$ & 17/11/99 & 6.8 & 38.7 & 58.8 & 64.2 & 15.0 & 176.7 & 129 & 25.6 & 110.6 & 3.7 \\
\hline litter & & 6.4 & 52.2 & 314.4 & 355.8 & 76.6 & 799.0 & 163.7 & 36.6 & 546.5 & 31.2 \\
\hline-15 & & 6.3 & 63.1 & 9.0 & 437.7 & 43.9 & 553.7 & 4.2 & 40.1 & 438.2 & 5.5 \\
\hline-25 & & 6.4 & 65.0 & 10.8 & 173.8 & 28.5 & 278.1 & 0.0 & 46.3 & 151.8 & 7.8 \\
\hline-55 & & 6.9 & 6.5 & 1.2 & 305.0 & 3.4 & 316.1 & 0.0 & 38.9 & 268.9 & 1.1 \\
\hline-90 & & 7.3 & 82.6 & 9.1 & 860.3 & 63.6 & 1015.7 & 1.8 & 61.4 & 880.1 & 3.1 \\
\hline
\end{tabular}

Throughfall solutions are mostly subacid; a few fairly acid episodes were however detected in 1997 and 1998. (Fig. 2). Such low throughfall $\mathrm{pH}$ values are normally associated with low EC of the solution, and were measured in the absence of leaves. The most acid throughfall sample $(\mathrm{pH} 4.5)$ was recorded in October 1997; the acidity on this occasion was due to unusual amounts of nitrates $\left(144.98 \mu\right.$ molc $\left.^{-1}\right)$, not balanced by alkaline cations. Sources of throughfall nitrate are uncertain. It is often high in the summer months, when it probably originates in biological processes; single nitrate peaks in fall $1997\left(144.98 \mu \mathrm{molc}^{-1}\right)$ or spring $1998\left(64.83 \mu \mathrm{molc}^{-1}\right)$ are however not readily explainable in these terms, but could rather be related to pollution inputs in specific meteorological conditions.
Generally speaking, the relation between throughfall nitrate and $\mathrm{pH}$ is not straightforward. When high nitrate is accompanied by high EC of the solution, $\mathrm{pH}$ does not drop much below 6; this suggests that nitrate acidity, from whatever source, is well buffered by cation release from the canopy. This release is highly variable (from a minimum of $110 \mu$ molc $^{-1}$ in late spring 1999 , to a maximum of $1594 \mu$ molc $^{-1}$ in summer 1998), reflecting variability in canopy processes and dry deposition inputs intercepted by the canopy and then washed in the throughfall.

Solutions exiting the soil organic layer are the most variable, and show the highest acidity peaks: $\mathrm{pH}$ values between 4.6 and 5.1 are not uncommon in samples collected in 1997 and 1998. Such peaks are again well re- 


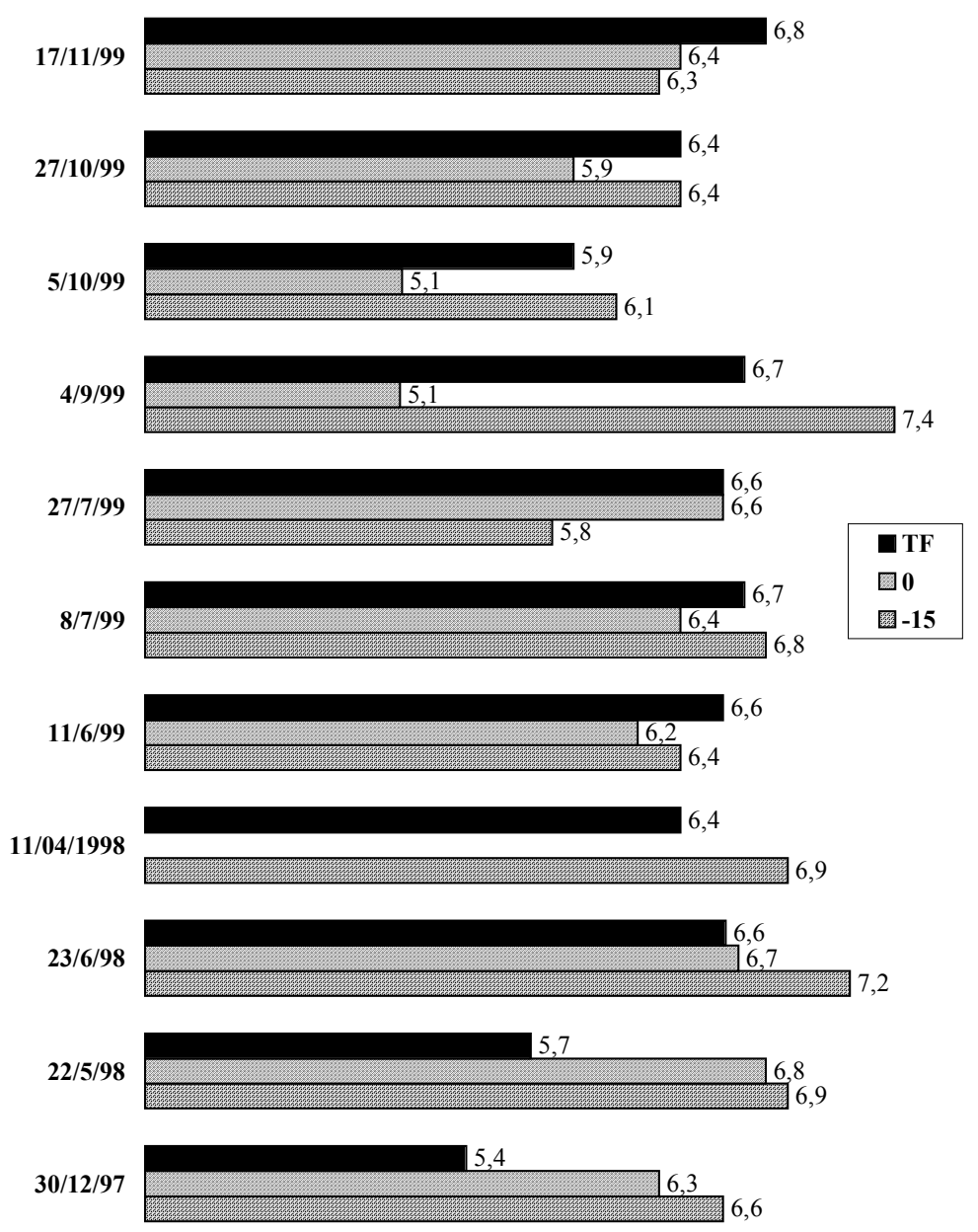

Fig. 2. pH values in throughfall, litter solution and solution at $15 \mathrm{~cm}$ depth, for representative sampling dates.

lated to high nitrate concentrations, in the 902 to 1357 $\mu$ molc $1^{-1}$ range. In this case, nitrate origin is traceable to litter biological processes. Very high nitrate concentrations appear in summer/early fall (late July-early October), when rates of litter biological decomposition are highest, while nitrates are typically very low in spring. Again, high nitrate exiting the litter layer is not directly linked to solution $\mathrm{pH}$. While low solution $\mathrm{pH}$ is generally accompanied by high nitrate concentrations, not all nitrate-rich solutions are acid. Analysis of the ion balances (Fig. 3) shows that low pH is found when solution $\mathrm{Ca}$ is significantly lower than $\mathrm{NO}_{3}$, and this last represents the dominant solution anion. When $\mathrm{Ca}$ approximately equals $\mathrm{NO}_{3}$, the sum of cations significantly exceeds even the highest nitrate values, and an important anion deficit appears in the solution (Fig. 3). Anion deficit is normally ascribed to organic acids but, at the $\mathrm{pH}$ values common in such samples, a significant contribution from bicarbonate must be considered. When nitrate release is low, the soil organic layer actually buffers acid throughfall. The $\mathrm{pH}$ of the solution exiting the organic layer then appears strongly controlled by the different rates and epochs for the release of nitrates and cations from the litter itself.

Notwithstanding the variability of $\mathrm{pH}$ in the solutions exiting the organic layer, solutions sampled at 15 $\mathrm{cm}$ depth always appear to be well-buffered, even when the most acidic solutions are found exiting the litter layer. Buffering within the upper $15 \mathrm{~cm}$ of mineral soil is invariably accompanied by disappearance of nitrates (Fig. 3). The 0-15 cm mineral soil layer, which includes the A1 horizon, thus removes nitrates with an effectiveness which is substantially independent from the nitrates released by the overlying organic horizons.

Such efficient removal can only be explained in terms of uptake by a nitrogen-limited biota, and is probably enhanced by the chemical conditions in the A1 horizon. This high base status of $\mathrm{A} 1$, constantly replenished by biological processes, enables it to buffer the solution. These same conditions probably generate a favorable environment for microbial biomass and plant feeder roots, supporting effective nitrate uptake. 

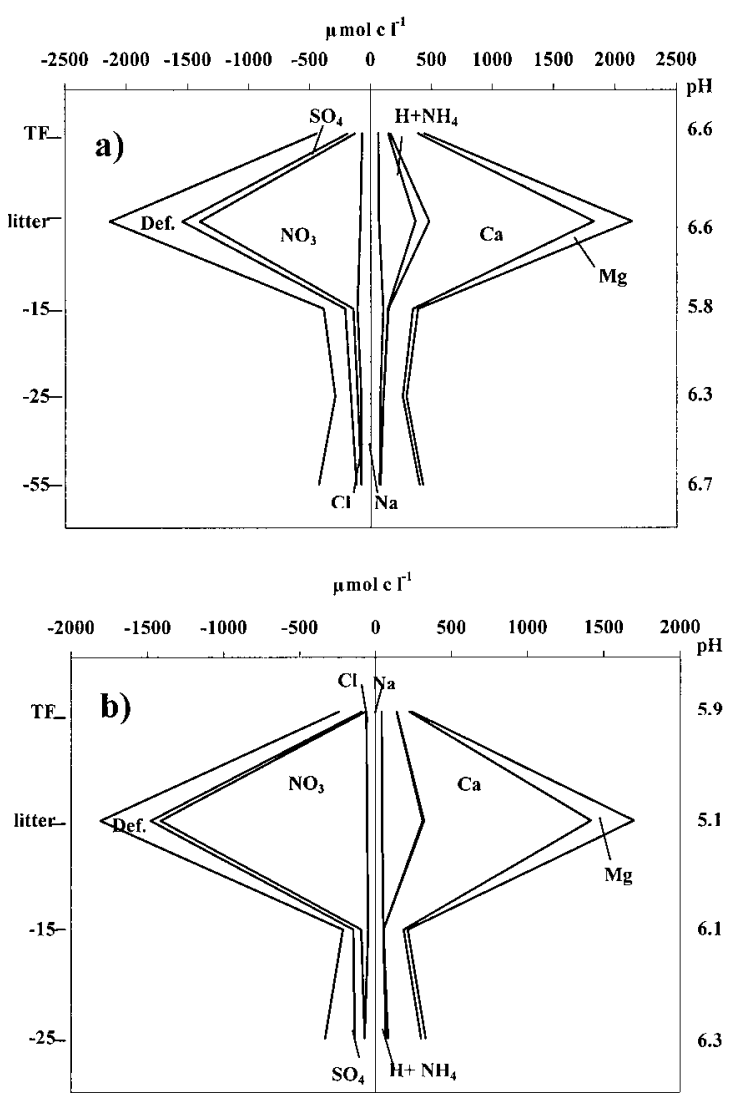

Fig. 3. Plot of charge balance for solutions collected in: a) $27 / 7 / 99$; b) $5 / 10 / 99$; both represent strong nitrate release pulses from litter, but only in 5/10/99 a really acidic solution is created, as in $27 / 7 / 99 \mathrm{Ca}$ is definitely greater than nitrate, and balanced by anion deficit.

Below $15 \mathrm{~cm}$, soil solution $\mathrm{pH}$ does not change much, though a slight decrease is the most common trend. Mineral horizons below A1, especially A2 and $\mathrm{AB}$, are quite acid, so the changes in solution $\mathrm{pH}$ are consistent with seepage through an acidic environment which, however, lacks reactive enough acidity sources to effect major changes in a solution rich in $\mathrm{Ca}$ and poor in strongly acidic anions.

Frequent large increases in total ion concentration in the deepest samples, ranging between 300 and 1100 $\mu$ molc $1^{-1}$, are mainly due to raised Ca concentration, associated with an anion deficit. This trend is typical of soils working under the dominant influence of the bicarbonate anion (Ugolini \& Sletten 1991).

Sulfate input at throughfall and litter level is moderate, but highly variable. The highest sulfate concentrations, in the 100-250 $\mu$ molc $\mathrm{l}^{-1}$ range, may or may not be accompanied by high concentrations of nitrate. As sulfate originates biologically from protein mineralization, it can be assumed to be of such origin only when correlated to nitrate. In the other cases, sulfate appears at throughfall level, and should then be of external origin, via either pollution or the dry deposition of sulfate-rich dusts. High sulfate concentrations with low or average nitrate levels are well correlated to high $\mathrm{pH}$ and $\mathrm{Ca}$ concentration in the throughfall, and are more frequent in summer. These sulfate inputs appear to be due to the deposition of airborne dust of African origin, blown by summer southerly winds (Lenaz et al. 1986). Variable summer sulfate deposition can be explained by the variable composition of these dusts, which do not always tap sulfate (gypsum)-rich sources.

\section{DISCUSSION}

\subsection{Soil genesis processes and environmental relations}

Nonallophanic Andosols develop from volcanic ash weathering in cool, humid climates, under continuous forest cover. Their genesis is marked by intense leaching of base cations and production of organic complexing agents; these represent a strong Al sink, preventing formation of allophanic compounds. In contrast, intense $\mathrm{Al}$ and $\mathrm{Fe}$ release from fast-weathering ash hampers mobilization of metal-organic complexes, and metal depletion from surface horizons. The result is an accumulation of immobile metal-organic complexes; clay minerals also form, taking up cations that exceed the complexing capacity and are not readily leached. Soils characterized by mobile metal-organic complexes, i.e. Spodosols, form from ashes only in the most severe bioclimatic conditions, in high rainfall areas under conifer forests (Shoji et al. 1993; Ugolini et al. 1977).

All the sola in site ABR1 have been subjected to the processes of nonallophanic Andosol formation, but to different degrees. The upper solum, Aluandic Umbrisol, has all the chemical characteristics of Andosols, but lacks the physical ones; this is probably because there is too high a fraction of Terra rossa in its parent material. The lower solum is characterized by the same processes but to a lesser extent. As it is buried by the upper solum, it is probably older, and formed under somewhat less aggressive, possibly warmer and drier, climatic conditions.

The properties of such a soil complex, as regards the typical acidification hazards in forest soils, are not easy to evaluate. There is little doubt that the soil has limited buffering power, with the exception of the surface horizon. Anthropogenic acidification is in any case strongly linked to anion loading and, from this point of view, the potential for anion retention is very considerable (Dahlgren et al. 1990; Karltun \& Gustafsson 1993; Robarge \& Johnson 1992). The soil shows large pools of "active" metal fractions, which could provide important stocks of anion adsorption sites. The reverse of the medal is that such pools can also act as sources of potentially toxic $\mathrm{Al}$, should conditions for $\mathrm{Al}$ release occur as a result of anthropogenic acidification (Matzner \& Prenzel 1992; Ulrich et al. 1980).

A more precise evaluation of potential soil response to anthropogenic acidification would require specific experiments, addressing issues such as the distribution of positive and negative charges and the actual sulfate 
adsorption isotherms. An alternative way of evaluating soil reaction to acidifying loads is by monitoring soil solutions. Basic observations on soil solid phase coupled, with continuous solution monitoring, can lead to a better definition of soil behavior, at least as regards current levels of external inputs.

\subsection{Solid phase-solution interactions}

The difference between soil and solution $\mathrm{pH}$ is large, possibly larger than usual, even accounting for the influence of high-specific-surface, Al-saturated colloids on solid phase $\mathrm{pH}$ measurement. The reason for the apparent inability of the solid phase to further acidify the solution is unclear. The immobility of organic acids and the low effective exchangeability of adsorbed $\mathrm{Al}$, as evidenced by the behavior of $\mathrm{pH}$ in $\mathrm{KCl}$, should however play a role. Further experiments to ascertain the dynamics of this interaction might be worthwhile.

If sulfate loading at the soil surface does not appear to be of serious concern in terms of anthropogenic acidification, the variable and significant amounts detected can still represent a test of soil sulfate retention capacity. From this point of view, it is interesting to analyze the depth trends of soil solution sulfate. In most cases, sulfate input from the litter layer is low; in these cases, sulfate concentration in the soil solution almost invariably increases with depth. This could be partly due to concentration of the soil solution, as it penetrates farther into the soil and the water is progressively tapped by plants. However, chloride depth trends show that the effect of this concentration is not very strong; some sulfate release from the mineral horizons may then be suspected. With a high sulfate input, there is a reverse in depth distribution, and marked retention is evident as sulfate-laden solutions move through the soil. This behavior is typical of an equilibrium adsorbant, fairly saturated with respect to the adsorbed ion. High sulfate concentrations cause sulfate retention but, apparently, adsorbed sulfate is then slowly released, as soon as the amount of sulfate in the solution decreases and the equilibrium shifts. This takes place at low absolute sulfate loading values, supporting the hypothesis that the potential for sulfate retention in this soil is actually low. The potentially large pool of anion adsorbants, highlighted by soil solid phase analysis, is then not very effective. The best explanation for this can be found in the strength, and saturated character, of the metal-humus complexes: the large amounts of active $\mathrm{Fe}$ and $\mathrm{Al}$ appear to be so strongly associated to organic matter that they actually maintain relatively few free positive charges.

\section{CONCLUSIONS}

The combination of soil solid phase analysis and soil solution monitoring enabled us to make a fairly extensive characterization of the actual soil conditions and potential soil acidification risk in site ABR1. This site appears to be subjected to low acidifying loads, which are fairly effectively buffered by the forest-soil system.

However, it is clear that this situation is not intrinsically stable, but depends strongly on both extrinsic factors and easily reversible soil conditions. The possible soil reaction to higher loading and less favorable management cannot be safely evaluated as positive.

First of all, acidity buffering is effective at the present low loads, while there is no guarantee as to the effects of higher loads. Buffering relies heavily on two factors: external inputs and the functionality of a thin, surficial soil horizon. Alkaline dust deposition is characteristic of Mediterranean environments, but its effectiveness depends in part on the canopy structure, which presently constitutes an efficient dust trap. The role of the soil A1 horizon is clearly the most sensitive: at the moment, it represents the last barrier for any sort of acidic load. The marked differentiation of this horizon from the rest of the soil suggests that its characteristics have developed as a response to recent management changes. The major decrease in cutting rates and the abandonment of litter harvesting are changes likely to have favorably influenced soil surface biological base replenishment, allowing the A1 horizon to evolve towards its current high base status. Of course, these conditions are also closely linked to the presence of a deciduous species. Potential acidification risks also come from the low sulfate retention capability of the soil, though sulfates are now being removed as an anthropogenic acidifying load.

The integration of soil solid phase and solution investigations has proved very useful in assessing the acidification risks in site ABR1. Our results show that forecasting soil behavior under external loading may be of doubtful value, if based only on solid phase studies. A reasonable expert assessment of the ABR1 soil, on the basis of solid phase data alone, would result in the soil being considered deficient in acidity buffering capability, but potentially effective in anion retention. Combined soil solution analysis has produced nearly opposite results, as the actual behavior of the soil versus acidification and anion loading was tested. The complexity of the interactions between soil solid phase and solution properties strongly suggests that we have to identify new parameters for assessing soil response and critical acidifying loads, to be used in those cases in which soil solution monitoring is not feasible. In particular, more effective characterization is needed for both soil buffering capacity and anion retention potential.

\section{REFERENCES}

Adams, F. 1974. Soil solution. In: E.W. Carson (Ed.), The Plant Root and Its Environment. University of Virginia Press, Charlottesville, VA, USA: 441-481.

Alewell, C., M. Bredemeier, E. Matzner \& K. Blanck. 1997. Soil solutions response to experimentally reduced acid deposition in a forest ecosystem. J. Environ. Qual., 26: 658-665. 
Alianiello, F., F.A. Biondi, C. Ferrari, G. Mecella \& L. Nisini. 2002. Forest soil conditions in the CONECOFOR Permanent Monitoring Plots and in the Level I Network in Italy. In: Mosello, R., B. Petriccione \& A. Marchetto (Eds), Long-term ecological research in Italian forest ecosystems. J. Limnol., 61 (Suppl. 1): 25-35.

Allavena, S., R. Isopi, B. Petriccione \& E. Pompei. 1999. Programma Nazionale Integrato Per Il Controllo Degli Ecosistemi Forestali; Primo Rapporto - 1999. MiPAF, Roma: $167 \mathrm{pp}$.

Barnhisel, R.I. \& P.M. Bertsch. 1989. Chlorites and hydroxyinterlayered vermiculite and smectite. In: J.B. Dixon \& S.B. Weed (Eds), Minerals in soil environments. SSSA book 1. SSSA, Madison, WI, USA: 729-788.

Bredemeier, M. 1987. Quantification of ecosystems-internal proton production from the ion balance of the soil. Plant and Soil, 101: 273-280.

Carnicelli, S., A. Mirabella, G. Cecchini \& G. Sanesi. 1997. Weathering of chlorite to a low charge expandable mineral in a Spodosol on the Apennine mountains - Italy. Clays and Clay Minerals, 45(1): 28-41.

Dahlgren, R. A., D. C. McAvoy \& C.T. Driscoll. 1990. Acidification and recovery of a Spodosol Bs horizon from acidic deposition. Environ. Sci. Technol., 24: 531-537

David, M. B \& C.T. Driscoll. 1984. Aluminium speciation and equilibria in soil solutions of a Haplorthod in the Adirondack Mountains (New York, U.S.A.). Geoderma, 33: 297 318.

Ferrari, G.A. \& P. Malesani. 1973. Micromorphology and mineralogy of some acid brown soils (Umbrepts) in the meadows of the central calcareous Apennine (Abruzzo-Italy). Atti Soc. Tosc. Sci. Nat. Mem. Serie A, LXXX: 5967.

Karltun, E. \& J. P. Gustafsson. 1993. Interference by organic complexation of $\mathrm{Fe}$ and $\mathrm{Al}$ on the $\mathrm{SO}_{4}{ }^{2-}$ adsorption in Spodic B horizons in Sweden. J. Soil Sci., 44: 625-632.

Kaiser, K. \& W. Zech. 1996. Defects in estimation of aluminium in humus complexes of podzolic soils by pyrophosphate extraction. Soil Science, 161(7): 452-458.

Johnson, D.W., D.D. Richter, H. van Miegroet, D.W. Cole \& J.M. Kelly. 1986. Sulphur cycling in five forested ecosystems. Water, Air and Soil Poll., 30: 965-979.

ISSS-ISRIC-FAO. 1998. World reference base for soil resources. World soil resources report 84 . FAO, Rome: 88 pp.

Lenaz, R., V. Landuzzi \& L. Tomadin. 1986. Apports et concentrations de masse de poussiéres eoliennes sur le bassin oriental et occidental de la Mediterranée. Mem. Soc. Geol. It., 36: 189-200.

Litaor, M. I. 1988. Review of soil solution samplers. Water Resour. Res. , 24: 727-733.

Marschner, B., A. Gensior \& U. Fischer. 1998. Response of soil solution chemistry to recent declines in atmospheric deposition in two forest ecosystems in Berlin, Germany. Geoderma, 83: 83-101.

Matzner, E. \&J. Prenzel. 1992. Acid deposition in the German Solling area: effects on soil solution chemistry and Al mobilization. Water, Air and Soil Poll., 61:221-234.

Matteucci, G. 1998. Bilancio del carbonio in una faggeta dell'Italia Centro-Meridionale: determinanti ecofisiologici, integrazione a livello di copertura e simulazione dell'impatto dei cambiamenti ambientali. Tesi di dottorato, Università degli studi di Padova. Padova: 227 pp.

Matteucci G., S. Dore, A. Masci \& G. Scarascia Mugnozza. 1997. The CANIF EU project: activities and results of the research performed in Italy in a beech forest and a spruce plantation. In: Valentini R. \& A. Ghazi (Eds), Proc. Int. Workshop "Greenhouse gases and their role in climate change: the status of Research in Europe". Orvieto, 12-14 Nov 1997.

Meesenburg, H., K.J. Meiwes \& P. Rademacher. 1995. Long term trends in atmospheric deposition and seepage output in northwest Germany forest ecosystems. Water, Air and Soil Poll., 85: 611-616.

van Reeuwijk, L.P., 1992. Procedures for soil analysis. ISRIC, Wageningen, NL.

Robarge, W.P. \& D.W. Johnson. 1992. The effects of acid deposition on forested soils. Adv. in Agronomy, 47: 1-83.

Sanesi, G. \& G. Cecchini. 1999. I suoli delle faggete: caratteristiche ed aspetti funzionali. In: G. Scarascia Mugnozza (Ed.), Ecologia strutturale e funzionale di faggete italiane. Edagricole, Bologna: 71-79.

Shoji, S., M. Nanzyo \& R. Dahlgren. 1993. Volcanic ash soils - genesis, properties and utilization. Elsevier, Amsterdam: $288 \mathrm{pp}$.

Ugolini, F.C., R. Minden, H Dawson \& J. Zachara. 1977. An example of soil processes in the Abies amabilis zone of Central Cascades, Washington. Soil Sci., 124: 291-302.

Ugolini, F.C. \& R.A. Sletten. 1991. The role of proton donors in pedogenesis as revealed by soil solution studies. Soil Sci., 151: 59-75.

Ulrich, B., R. Mayer \& P. K. Khanna. 1980. Chemical changes due to acid precipitation in a loess derived soil in central Europe. Soil Sci., 130: 193-199. 